\title{
New record and description of the male gonopods of Paeduma cylindraceum (Bell, 1859) from the tropical eastern Pacific (Decapoda, Brachyura, Hexapodidae)
}

\author{
Michel E. HENDRICKX \\ Unidad Académica Mazatlán, Instituto de Ciencias del Mar y Limnología, \\ Universidad Nacional Autónoma de México, \\ PO Box 811, Mazatlán, Sinaloa 82000 (Mexico) \\ michel@ola.icmyl.unam.mx
}

Eva VISAUTA-GIRBAU

GEOMARE A.C., Av. Miguel Alemán 616-4B, Mazatlán, Sinaloa 82040 (Mexico)

\section{KEY WORDS \\ Hexapodidae, \\ Paeduma cylindraceum, \\ new record, \\ male gonopods.}

MOTS CLÉS

Hexapodidae, Paeduma cylindraceum, nouvelle signalisation, gonopodes mâles.
Hendrickx M. E. \& Visauta-Girbau E. 2013. - New record and description of the male gonopods of Paeduma cylindraceum (Bell, 1859) from the tropical eastern Pacific (Decapoda, Brachyura, Hexapodidae). Zoosystema 35 (1): 89-96. http://dx.doi.org/10.5252/z2013n1a7

\section{ABSTRACT}

A new record is provided for the rarely collected hexapodid crab Paeduma cylindraceum (Bell, 1859), extending its distributional range to the southeastern Gulf of California, Mexico. The specimen, a large mature male of $13.7 \mathrm{~mm}$ carapace width, is the third ever collected since the male holotype was described. The male first gonopods are illustrated for the first time. The appendage shows unique features for the family, including a row of strong, marginal conical spine on the distal section of the shaft, and a crown of concentric series of strong, conical spines near tip.

\section{RÉSUMÉ}

Nouvelle signalisation et description des gonopodes mâles de Paeduma cylindraceum (Bell, 1859) de l'est du Pacifique tropical (Decapoda, Brachyura, Hexapodidae). Une nouvelle signalisation est fournie pour une espèce rare d'Hexapodidae Miers, 1886, Paeduma cylindraceum (Bell, 1859), qui étend son aire de distribution jusqu'au sud-est du golfe de Californie, Mexique. Le spécimen, un grand mâle adulte avec une largeur de carapace de $13,7 \mathrm{~mm}$, est le troisième spécimen recueilli depuis que l'holotype mâle a été décrit. La première paire de gonopodes du mâle est illustrée pour la première fois. Ils présentent une ornementation unique parmi les Hexapodidae comprenant une rangée de fortes épines coniques marginales sur la portion distale du gonopode ainsi que de fortes et nombreuses épines coniques subterminales, disposées en couronne. 


\section{INTRODUCTION}

The Hexapodidae Miers, 1886 is a small family of 21 species belonging to 13 genera, of which 11 are monotypic ( $\mathrm{Ng}$ et al. 2008). The complexity of the group has long been recognised and authors generally agree that a detailed comparison of all species currently included in the family is needed (see Manning \& Holthuis 1981; Guinot 2006; Guinot et al. 2010). Two species belonging to two monotypic genera have been reported from the eastern Pacific: Stevea williamsi (Glassell, 1938) from Guatemala (type locality), and Paeduma cylindraceum (Bell, 1859), from the Galápagos Islands (questionable type locality) and the Gulf of Tehuantepec, Mexico (Guinot et al. 2010).

Stevea williamsi was originally described in Hexapus De Haan, 1835, and transferred to a new, monotypic genus, Stevea Manning \& Holthuis, 1981. Paeduma cylindraceum was originally described in the genus Amorphopus Bell, 1859, a preoccupied genus name of Insecta. A new replacement name, Paeduma Rathbun, 1897, was assigned to this monotypic genus. The status of both species has been recently reviewed in details by Guinot (2006) and Guinot et al. (2010).

Stevea williamsi is still only known from the female holotype, not a male as erroneously stated by Glassell (1938), Manning \& Holthuis (1981), and Guinot (2006) (see Guinot et al. 2010 for details and a complete redescription of this species). Paeduma cylindraceum was briefly described by Bell (1859) and never reported again until recently. Indeed, Guinot (2006) redescribed this species after the type material (dry but in good condition) was rediscovered in the Oxford University Museum (OUMNH 15693). It was later found out that a female specimen from the Gulf of Tehuantepec, Mexico, identified as Stevea williamsi and kept at the Smithsonian Institution (USNM 170897), Washington D.C., actually belonged to P. cylindraceum (see Guinot et al. 2010). There are therefore two specimens available for $P$. cylindraceum.

Recent sampling along the southeastern coast of the Gulf of California, Mexico, allowed the collection of a third specimen of $P$. cylindraceum, a mature male, representing a range extension of this species by about nine degrees of latitude to the north. It also provides the opportunity to examine the male gonopods of this species, yet undescribed to date.

\section{MATERIAL AND METHODS}

The specimen on which this study is based was collected with an artisanal shrimp trawl net during an annual sampling carried out by INAPESCA (Mexico) along the east coast of the Gulf of California, Mexico, in April 2007. Photographs were taken with a Canon S3 IS camera. A scanning electron microscope was used to photograph the first pair of gonopods. Line drawings of gonopods 1 and 2 were made using a camera lucida attached to a Leica MZ6 dissecting microscope.

\section{ABBREVIATIONS}

EMU regional collection of Marine Invertebrates, Instituto de Ciencias del Mar y Limnología, UNAM;

CW carapace width;

CL carapace length.

\section{TAXONOMIC ACCOUNT}

Order DECAPODA Latreille, 1802

Infraorder BRACHYURA Latreille, 1802

Family HEXAPODIDAE Miers, 1886

Genus Paeduma Rathbun, 1897

Paeduma cylindraceum (Bell, 1859)

(Figs 1;2)

Amorphopus cylindraceus Bell, 1859: 27.

Paeduma cylindraceum. - Rathbun 1897: 163. — Guinot 2006: 559, figs 1, 2 (complete synonymy). - $\mathrm{Ng}$ et al. 2008: 86 (list). —- Guinot et al. 2010: 287, fig. $1 \mathrm{E}$.

Material examined. - 1 o (CW $13.7 \mathrm{~mm}$; CL $9.0 \mathrm{~mm}$ ), off Santa Maria la Reforma Bay $\left(24^{\circ} 44^{\prime} 42^{\prime \prime} \mathrm{N}\right.$, $108^{\circ} 02^{\prime} 04^{\prime \prime}$ W), Sinaloa, Mexico, 02.IV.2007, trawl net, $3.5 \mathrm{~m}$ depth (coll. J. Madrid-Vera and E. Visauta-Girbau) (EMU-8270).

DisTribution. - The record from Galápagos for the holotype of $P$. cylindraceum has been questioned (see Guinot 2006 for details). The locality reported by Gui- 

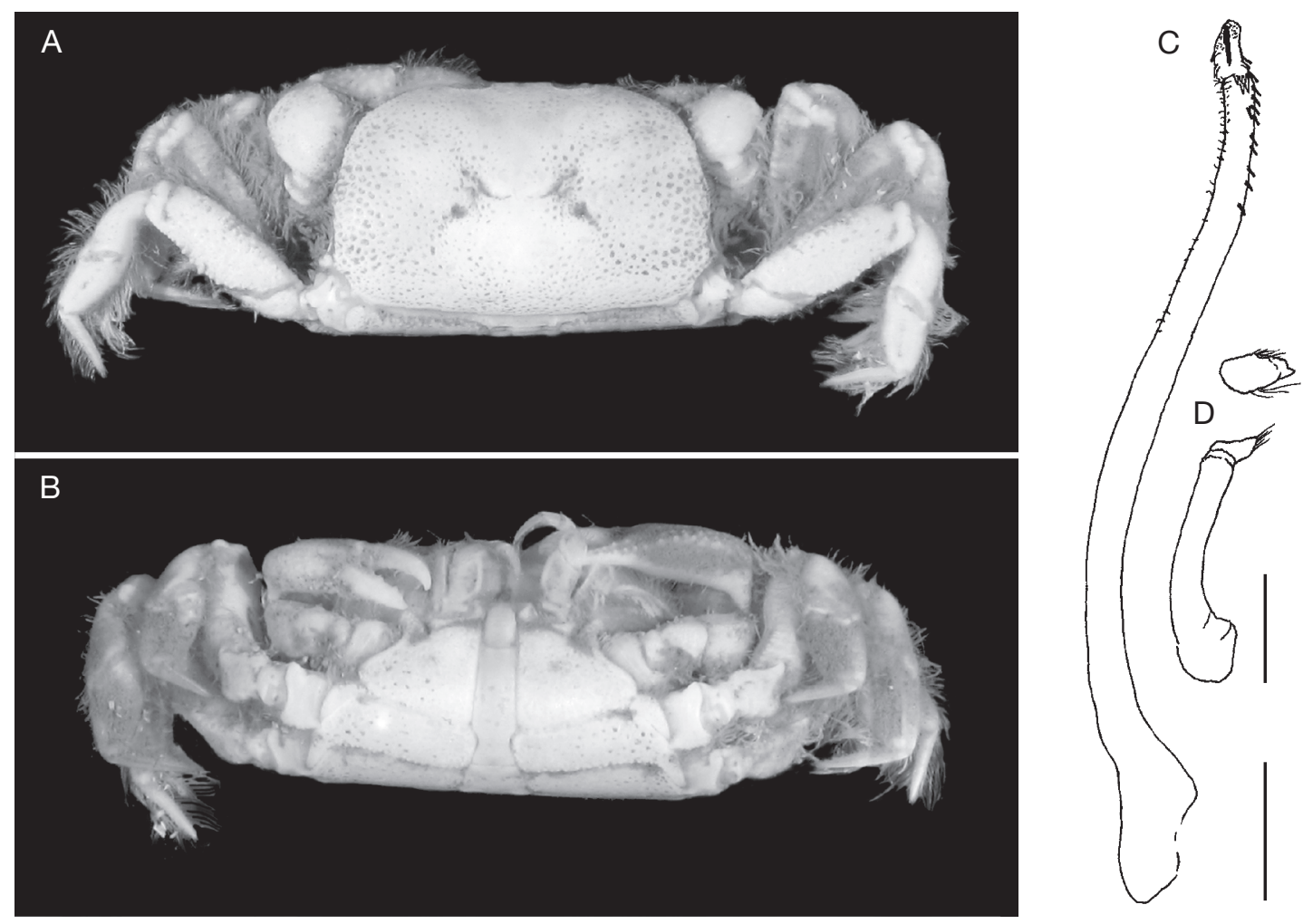

FIG. 1. - Paeduma cylindraceum (Bell, 1859), male (EMU-8270), CW $13.7 \mathrm{~mm}$ : A, dorsal view; B, ventral view; C, right first gonopod, ventral view; D, right second gonopod, ventral view, and dorsal view of tip. Scale bars: C, $1 \mathrm{~mm}$;, $0.5 \mathrm{~mm}$.

not et al. (2010: Gulf of Tehuantepec) corresponds to station 5 visited by the R/V The Stranger in 1939: off "Tenela Bar" (certainly "Tonala Bar"; approximately $\left.15^{\circ} 53^{\prime} 48^{\prime \prime} \mathrm{N}, 93^{\circ} 54^{\prime} 36^{\prime \prime} \mathrm{W}\right), 24-33 \mathrm{~m}$. Present record in the Gulf of California confirms that $P$. cylindraceum is not a Galápagos endemic as previously thought but rather a species with a wide geographic distribution along the tropical east Pacific region. Assuming that the Galápagos record is in error, P. cylindraceum would be part of the continental "Panamic tropical fauna" as defined by Garth (1946), occurring in the Gulf of California (the "Cortés" Province) and in the Gulf of Tehuantepec (within the Panamic Province). As observed for many species of Brachyura and other decapod crustaceans (see Garth 1946; Hendrickx 1992; Wicksten \& Hendrickx 2003), the vast majority of species occurring in the Gulf of California and south of this enclosed sea are likely to be found in Central America or even further south, to Colombia, Ecuador or northern Peru. We might therefore expect to find it in similar habitats between Mexico and Peru, within or close to shallow tropical bays, whenever adequate sampling is performed.

\section{REMARKS}

The male specimen represents a range extension of about nine degrees of latitude to the north and is in excellent condition, with all pereiopods attached and the abdomen intact (Fig. 1A, B). All characters described and illustrated by Guinot et al. (2010) are clearly observed in the specimen. These include the typical transverse-cylindrical form; strongly convex and laterally pitted carapace; conspicuously narrow abdomen with abdominal somites 3-5 fused, and a strong, proximal constriction in somite 6; the arrangement and size of thoracic sternites 1-8; and the apodemal platelet at the base of coxa 4 . The apodemal platelets are more reduced in the specimen examined than in the holotype on the left side, and even smaller (not discernible on Fig. 1B due to the angle between the coxa and the carapace) on the right side. 

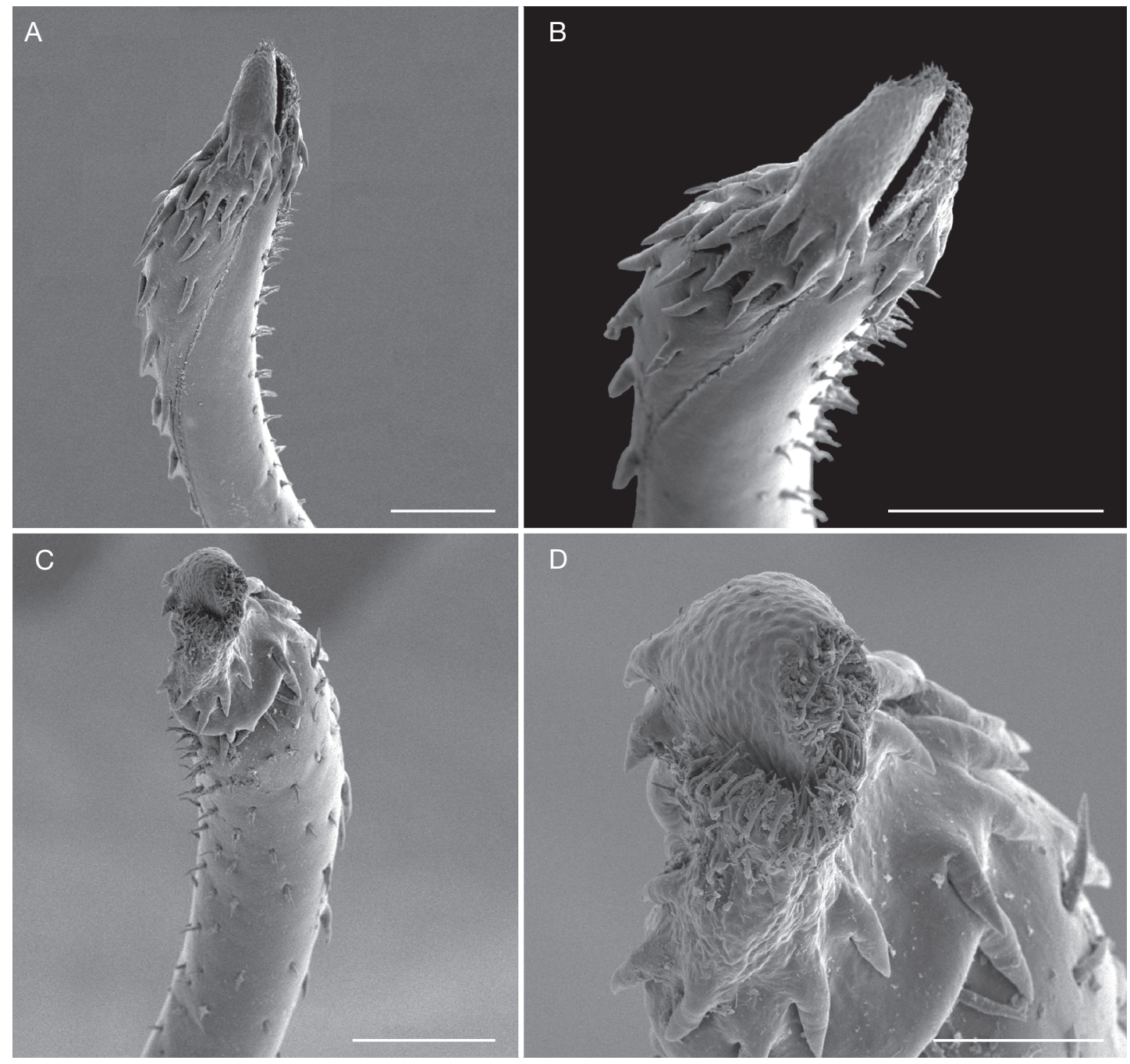

FIG. 2. - Paeduma cylindraceum (Bell, 1859), left first gonopod of male (EMU-8270): A, distal section of shaft, ventral view; B, same, details of tip; C, distal section of shaft, dorsal view; D, same, details of tip. Scale bars: A, C, $250 \mu \mathrm{m} ; \mathrm{B}, 300 \mu \mathrm{m} ; \mathrm{D}, 100 \mu \mathrm{m}$.

\section{DESCRIPTION OF GONOPODS}

Guinot (2006:557) noted in her emended diagnosis of Paeduma that a description of the male gonopods was impossible due to the dry condition of the holotype, the only male specimen available to that time. The examination of the gonopods was feasible because the male examined herein was originally preserved in formalin, and transferred to $70 \%$ ethanol shortly after.

Gonopod 1 as illustrated. Shaft long, slender, slightly sinuous, slightly inflated basally (Fig. 1C); terminal opening slit-like (Fig. 2A); inner face of shaft with one series of about 10 strong spines extending from just below tip in approximately distal $1 / 5$ of shaft length (Fig. 2A); outer face of shaft with rows of spinules extending from tip in approximately distal $1 / 3$ of shaft length (Fig. 2A); a few, dispersed, similar spinules on dorsal section of the shaft, near tip (Fig. 1C); in ventral view, tip of gonopod with crowded concentric series of strong, downwards-pointing, conical spines located 
A

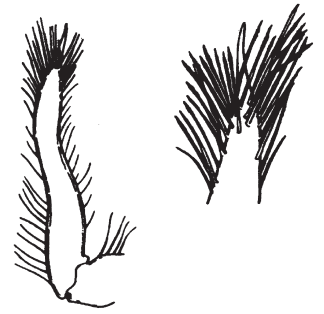

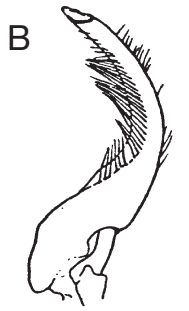

C
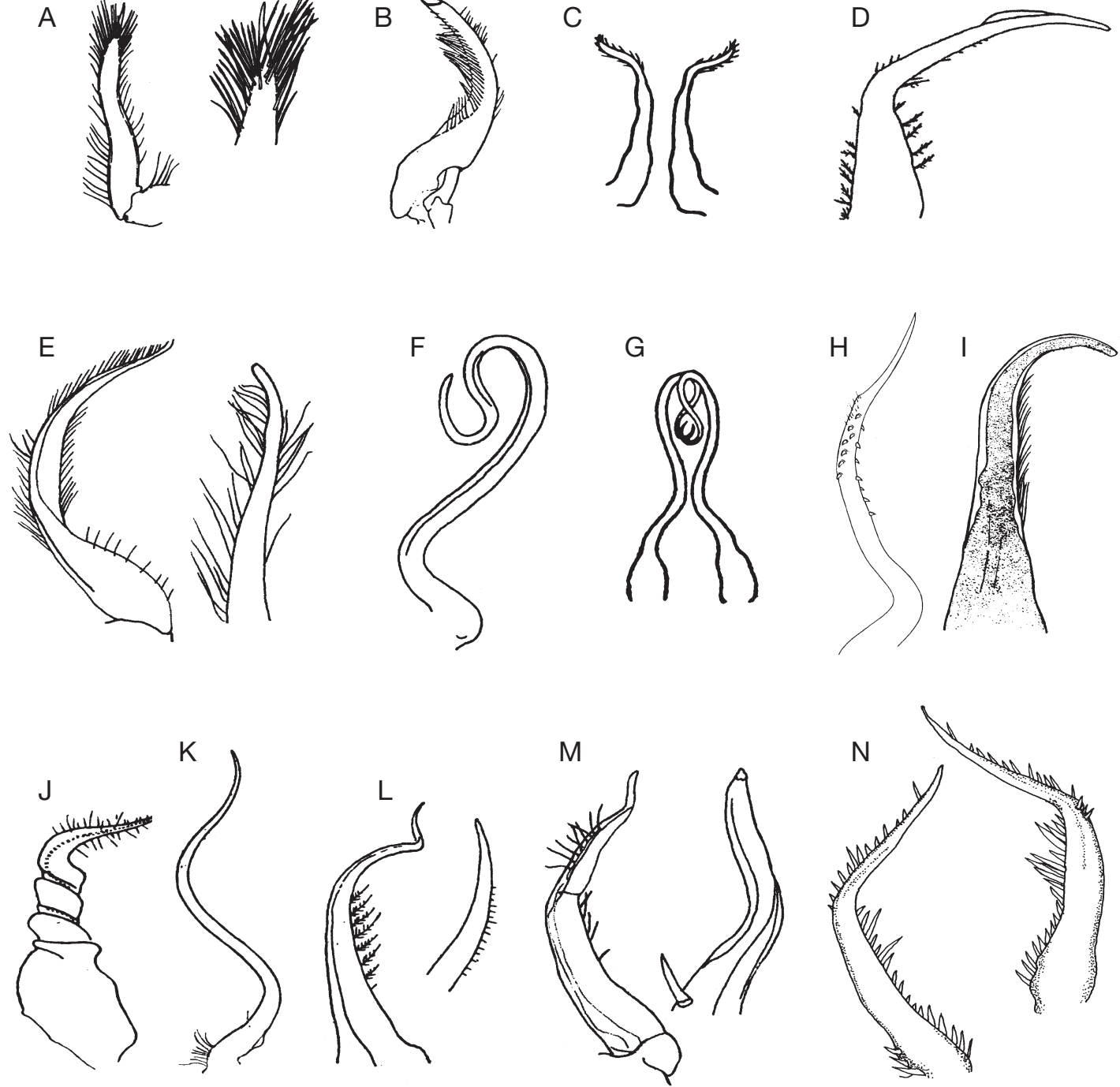

FIG. 3. - First gonopod of species of Hexapodidae Miers, 1886: A, Hexapinus buchanani (Monod, 1956); B, Hexapinus granuliferus (Campbel \& Stephenson, 1970); C, Hexapus anfractus (Rathbun, 1909); D, Hexapus estuarinus Sankarankutty, 1975; E, Hexapus sexpes (Fabricius, 1798); F, G, Hexalaughlia orientalis (Rathbun, 1909); H, Parahexapus africanus Balss, 1922; I, Pseudohexapus platydactylus Monod, 1956; J, Spiroplax spiralis (Barnard, 1950); K. Thaumastoplax anomalipes Miers, 1881; L, Trioplax stebbingi (Barnard, 1947); M, Tritoplax stephenseni (Serène \& Soh, 1976); N, Latohexapus granosus Huang, Hsueh \& Ng, 2002. A-C, G-L, from Manning \& Holthuis (1981); D, from Sankarankutty (1975); E, F, M, from Serène \& Soh (1976); N, from Huang et al. (2002).

next (mesial) to terminal opening and further below, one small patch of five or six similar, slightly curved spines located lateral to terminal opening (Fig. 2B); in dorsal view, tip of gonopod roughly rounded, rugged, with two strong lateral, conical spines, rugged area extending proximally as a roughly triangle-shaped rugged area with series of slender spines, subterminal crown of four or five strong, conical spines, similar to those in ventral view below triangle-shaped area, these spines overhanging a subcircular fleshy fold bordered with few strong spines (Fig. 2C, D). As predicted by Guinot (2006: 
TABLE 1. - Description of first gonopod in species of Hexapodidae Miers, 1886. Sources: A, Sankarankutty (1975); B, Serène \& Soh (1976); C, Manning \& Hothuis (1981); D, Huang et al. (2002); E, this contribution.

\begin{tabular}{|c|c|}
\hline Species & First gonopod description \\
\hline $\begin{array}{l}\text { Hexapinus buchanani } \\
\text { (Monod, 1956) (C) }\end{array}$ & $\begin{array}{l}\text { Shaft stout, almost vertical, basally narrow and of almost similar width throughout } \\
\text { its length, long setae on inner and outer margin; tip subacute, with more densely } \\
\text { set setae. }\end{array}$ \\
\hline $\begin{array}{l}\text { Hexapinus granuliferus (Campbell \& } \\
\text { Stephenson, 1970) (C) }\end{array}$ & $\begin{array}{l}\text { Shaft stout, basally wide, strongly curved; distal } 2 / 3 \text { with long, dense (inner margin) } \\
\text { and short, scarse (outer margin) setae; tip description not available. }\end{array}$ \\
\hline $\begin{array}{l}\text { Hexapus anfractus } \\
\quad \text { (Rathbun, 1909) (C) }\end{array}$ & $\begin{array}{l}\text { Shaft moderately long, basally wide and robust, tappering to a strongly bent } \\
\text { distal section, the latter with fringes of setae on inner and outer margins; no dista } \\
\text { ornamentations. }\end{array}$ \\
\hline $\begin{array}{l}\text { Hexapus estuarinus } \\
\quad \text { Sankarankutty, } 1975 \text { (A) }\end{array}$ & $\begin{array}{l}\text { Shaft moderately long, slender, bent at a } 45^{\circ} \text { angle at about mid-length; distal } \\
\text { (bent) half of shaft with few marginal setae; proximal half with marginal plumose } \\
\text { setae; a flared part along inner margin near tip, the latter subacute and without } \\
\text { ornamentations. }\end{array}$ \\
\hline $\begin{array}{l}\text { Hexapus sexpes (Fabricius, 1798) } \\
\text { (B) }\end{array}$ & $\begin{array}{l}\text { Shaft stout, basally wide, strongly curved; distal } 2 / 3 \text { with long, dense (inner margin) } \\
\text { and scarse (outer margin) setae; tip subacute, without ornamentations. }\end{array}$ \\
\hline $\begin{array}{l}\text { Hexalaughlia orientalis } \\
\quad \text { (Rathbun, 1909) (B, C) }\end{array}$ & $\begin{array}{l}\text { Shaft long, wide basally, narrowing regularly to a strongly bent }\left(180^{\circ}\right) \text { terminal } \\
\text { section forming a "S" (doubly recurved), this section about } 1 / 3 \text { the length of the rest } \\
\text { of the shaft; terminal (inverted) "S"-shaped sections of left and right gonopods } \\
\text { forming a " } 8 \text { ", tips acute, without ornamentations. }\end{array}$ \\
\hline $\begin{array}{l}\text { Parahexapus africanus } \\
\quad \text { Balss, } 1922 \text { (C) }\end{array}$ & $\begin{array}{l}\text { Shaft long, narrow, basally sigmoid, distal } 2 / 3 \text { slightly curved; mid-section of shaft } \\
\text { with series of strong conical spines and sparse setae; distal section naked, tappering } \\
\text { to an acute tip without ornamentations. }\end{array}$ \\
\hline $\begin{array}{l}\text { Pseudohexapus platydactylus } \\
\text { Monod, } 1956 \text { (C) }\end{array}$ & $\begin{array}{l}\text { Shaft stout; tip curved, bent at an angle of } 90^{\circ} \text {, a series of subterminal short setae } \\
\text { on inner margin, tip without ornamentations. }\end{array}$ \\
\hline $\begin{array}{l}\text { Spiroplax spiralis (Barnard, 1950) } \\
\text { (C) }\end{array}$ & $\begin{array}{l}\text { Shaft short, robust, base wide, mid-shaft } 3 \text {-spired; distal } 1 / 3 \text { bent at c. } 60^{\circ} \text {, margins } \\
\text { with short setae; tip acute, without ornamentations. }\end{array}$ \\
\hline $\begin{array}{l}\text { Thaumastoplax anomalipes } \\
\text { Miers, } 1881(\mathrm{C})\end{array}$ & $\begin{array}{l}\text { Shaft long, narrow, without spines or long setae ("almost naked"), strongly sigmoid } \\
\text { in proximal } 2 / 3 \text {, distal } 1 / 3 \text { slightly bent; tip acute, no distal ornamentations. }\end{array}$ \\
\hline $\begin{array}{l}\text { Tritoplax stebbingi (Barnard, 1947) } \\
\text { (C) }\end{array}$ & $\begin{array}{l}\text { Shaft basally very wide, proximal } 2 / 3 \text { robust, tappering and strongly curving distally; } \\
\text { distal end slender, bent at a } 90^{\circ} \text { angle in a vertical position, fringed with minute } \\
\text { setae on inner margin; tip acute, no distal ornamentations. }\end{array}$ \\
\hline $\begin{array}{l}\text { Tritoplax stephenseni (Serène \& } \\
\quad \text { Soh, 1976) (B) }\end{array}$ & $\begin{array}{l}\text { Shaft stout, basally wide, moderately curved; distal } 1 / 3 \text { with long, scarse setae on } \\
\text { inner margin, outer margin with scarse setae in mid-third; tip slightly bent, subacute, } \\
\text { with a subterminal conical tooth. }\end{array}$ \\
\hline $\begin{array}{l}\text { Latohexapus granosus Huang, } \\
\text { Hsueh \& Ng, } 2002 \text { (D) }\end{array}$ & $\begin{array}{l}\text { Shaft moderately long, slender, bent at a } 45^{\circ} \text { angle at about mid-length; dista } \\
\text { (bent) half of shaft with strong spines in the outer margin, and similar, slightly longer } \\
\text { spines in the inner margin of proximal half; tip subacute, without ornamentations. }\end{array}$ \\
\hline $\begin{array}{l}\text { Paeduma cylindraceum (Bell, 1859) } \\
\quad \text { (E) }\end{array}$ & $\begin{array}{l}\text { Shaft long, basally narrow, slightly sigmoid; distal } 1 / 3 \text { with short setae in outer } \\
\text { margin, inner margin with a row of strong conical spines in distal } 1 / 5 \text {; tip rounded, } \\
\text { ornamentated with crown of numerous conical, subterminal spines and short setae. }\end{array}$ \\
\hline
\end{tabular}

559), the gonopods of P. cylindraceum are "neither recurved posteriorly nor doubly recurved into an 8-shaped figure as in Hexalaughlia".

Gonopod 2 as illustrated. Short, about $1 / 6$ total length of gonopod 1 , slightly curved, tip bent at almost $90^{\circ}$ with shaft, suboval, flat in dorsal view, with few short setae (Fig. 1D).

In their extensive review of the West African brachyuran crabs, Manning \& Holthuis (1981: 166) presented a synthesis of all the species included in the family Hexapodidae at that time (11 genera, 16 species). They also presented a compilation of a key to genera in which they considered the shape and size of male first gonopods as an important diagnostic character for some genera. Furthermore, they provided illustrations (some of very poor definition and quality) of the male first gonopods for nine species belonging to eight genera (see Table 1): Hexapinus 
buchanani (Monod, 1956) and Hexapinus granuliferus (Campbell \& Stephenson, 1970); Hexapus anfractus (Rathbun, 1909); Paeduma orientale (Rathbun, 1909) (now included in the genus Hexalanghlia Guinot, 2006 fide Guinot 2006); Parahexapus africanus Balss, 1922; Pseudohexapus platydactylus Monod, 1956; Spiroplax spiralis (Barnard, 1950); Thaumastoplax anomalipes Miers, 1881; and Tritoplax stebbingi (Barnard, 1947). Manning \& Holthuis (1981: fig. 34) also provided an illustration of the male abdomen of Lambdophallus sexpes Alcock, 1900, showing the first gonopods with an acute tip, apparently devoid of any ornamentation. Manning \& Holthuis (1981) did not reproduce the description of the male first gonopod of Hexapus estuarinus Sankarankutty, 1975, and overlooked the contribution of Serène $\&$ Soh (1976) who illustrated the first gonopods of their new species Hexapus stephenseni Serène \& Soh, 1976 (transfered to Tritoplax Manning \& Holthuis, 1981; see $\mathrm{Ng}$ et al. 2008 ), and of two previously described species, Hexalaughlia orientalis (Rathbun, 1909), as Thaumastoplax Miers, 1881, and Hexapus sexpes (Fabricius, 1798). The first gonopods of the family have also been illustrated for Latohexapus granosus Huang, Hsueh \& Ng, 2002 (Table 1; Fig. 3). We are not aware of other descriptions of the male first gonopods in other species of hexapodids.

When comparing the major characteristics of gonopods of each species (see Table 1; Fig. 3), it becomes clear that there is a wide variety in the shape of gonopods among members of the Hexapodidae as currently recognised. The first gonopods can be either short and stout, long (filiform) and curving, or even short and spiralling. In most cases, the tip is acute to subacute, straight to strongly bent or even doubly recurved, and without any ornamentations (distal setae present in some cases), except in the case of Paeduma cylindraceum, where rows and a complex crown of stout conical spines are observed. These variations could reflect the diversity of genera within the family, as does the presence or absence of sternal grooves or trenches (see Manning \& Holthuis 1981), or the variation in the abdominal holding mechanism (see Guinot et al. 2010). Guinot (2006) indicated that a review on the position of Hexapodidae within the Brachyura is in progress. These variations will certainly prove to be of importance among other morphological features, and characters derived from first gonopods structure will certainly contribute to clarify the phylogenetic position of Hexapodidae within the Brachyura.

\section{Acknowledgements}

The authors are thankful to Montserrat Demestre and José Manuel Fortuño (CSIC, Barcelona) for their support and help with the SEM photographs. We thank Danièle Guinot (Muséum national d'Histoire naturelle, Paris) for supplying literature, Mercedes Cordero for editing the final manuscript and the SEM photographs, Juan Madrid for his help during sampling activities, and José Salgado for providing the photographs of Figure 1. We are grateful to Peter Castro, Tomoyuki Komai and Annemarie Ohler for their helpful comments on the manuscript. We also wish to thank the project "Evaluation of the shrimp stock on the Sinaloa coast", INAPESCA-Mazatlán, Mexico, for the support during sampling activities.

\section{REFERENCES}

BELL T. 1859. - Description of a new genus of Crustacea, of the family Pinnotheridae, in which the fifth pair of legs are reduced to an almost imperceptible rudiment. Journal of the Proceedings of the Linnean Society of London (Zoology) 3: 27-29.

GARTH J. S. 1946. - Littoral brachyuran fauna of the Galapagos Archipelago. Allan Hancock Pacific Expeditions 5 (10): 341-601.

GLASSELL S. A. 1938. - New and obscure decapod Crustacea from the west American coast. Transactions of the San Diego Society of Natural History 8 (33): 411-454.

GUINOT D. 2006. - Rediscovery of the holotype of Paeduma cylindraceum (Bell, 1859) and description of a new genus of Hexapodidae (Decapoda, Brachyura). Zoosystema 28 (2): 553-571.

Guinot D., De Angeli A. \& Garassino A. 2010. Holthuisea, a new genus from the Eocene of Italy (Decapoda, Brachyura, Hexapodidae), in Fransen C., De Grave S. \& Ng P. (eds), Studies on Malacostraca: Lipke Bijdeley Holthuis Memorial Volume. Crustaceana Monographs 14. Brill, Leiden: 283-304.

HENDRICKX M. E. 1992. - Distribution and zoogeographic affinities of decapod crustaceans of the Gulf of California, Mexico. Proceedings of the San Diego Society of Natural History 27: 1-9. 
Huang J.-F., Hsueh P-W. \& NG P. K. L. 2002. — Crabs of the family Hexapodidae (Decapoda: Brachyura) from Taiwan, with description of a new genus and new species. Journal of Crustacean Biology 22 (3): 651-660.

Manning R. B. \& Holthuis L. B. 1981. - West African brachyuran crabs (Crustacea: Decapoda). Smithsonian Contributions to Zoology 306: 1-379.

NG P. K. L., Guinot D. \& DAVIE P. J. 2008. — Systema Brachyurorum: Part I. An annotated checklist of extant brachyuran crabs of the world. The Raffles Bulletin of Zoology 17: 1-286.

RATHBUN M. J. 1897. - A revision of the nomenclature of the Brachyura. Proceedings of the Biological Society of Washington 11: 153-167.
SANKARANKUTTY C. 1975. - On a new species of Hexapus De Haan (Decapoda, Goneplacidae) from Cochin. Crustaceana 28 (1): 1-6.

SERÈne R. \& SoH C. L. 1976. - Brachyura collected during the Thai-Danish expedition (1966). Phuket Marine Biological Center Research Bulletin 12: 1-57.

WiCKSTEN M. K. \& HeNdRicKX M. E. 2003. - An updated checklist of benthic marine and brackish water shrimps (Decapoda: Penaoidea, Stenopodidea, Caridea) from the eastern tropical Pacific, in HENDRICKX M. E. (ed.), Contributions to the Study of East Pacific Crustaceans 2. [Contribuciones al Estudio de los Crustáceos del Pacífico Este 2.] Instituto de Ciencias del Mar y Limnología, UNAM, Mexico: 49-76.

Submitted on 22nd May 2012; accepted on 4 October 2012; published on 29 March 2013. 